ISSN 0103-5150

Fisioter. Mov., Curitiba, v. 28, n. 1, p. 149-156, Jan./Mar. 2015

Licenciado sob uma Licença Creative Commons

DOI: http://dx.doi.org.10.1590/0103-5150.028.001.A015

(c)

\title{
Balance assessment in people with chronic obstructive pulmonary disease
}

\author{
Avaliação do equilíbrio em portadores de \\ doença pulmonar obstrutiva crônica
}

Michelle Difante Pedrozo, Aron Ferreira da Silveira*

Universidade Federal de Santa Maria (UFSM), Santa Maria (RS), Brazil

\begin{abstract}
Introduction: Body balance is one of the most important functions of the organism and is directly associated with quality of life. Thus, given that chronic obstructive pulmonary disease (COPD) causes pulmorary alterations as well as several systemic complications, it is extremely important to make a careful investigation of its implications for body stability. Objective: To assess the balance of individuals with COPD by using Foam-Laser Dynamic Posturography. Materials and methods: 29 patients (19 men and 10 women; mean age $64.72 \pm 7.67$ years) who were former smokers and had COPD GOLD II and III were selected to participate in the study group. The control group was composed of 24 individuals (12 women and 12 men; mean age $63.58 \pm 8.17$ years) who did not have COPD. To assess the balance of participants, we used Foam-Laser Dynamic Posturography. Results: With regard to the Foam-Laser Dynamic Posturography test, we found no significant differences $(\mathrm{p}<0.05)$ between the experimental and the control group when compared to the variables of the SOT tests (SOT I to VI) or to the variables of the sensory analysis, i.e., somatosensory, visual and vestibular functions, and visual preference. Conclusion: This
\end{abstract}

\footnotetext{
* MDP: PhD, e-mail: aronfer@gmail.com

AFS: MSc, e-mail: michelledifante@yahoo.com.br
} 
study demonstrated that subjects with and without COPD showed a similar performance in the FoamLaser Dynamic Posturography test.

Keywords: Postural balance. Pulmonary Disease Chronic Obstructive. Vestibule labyrinth. Proprioception. Posture.

\section{Resumo}

Introdução: $O$ equilíbrio corporal é uma das funções mais importantes do organismo e está diretamente associado à qualidade de vida. Assim, o fato de a Doença Pulmonar Obstrutiva Crônica (DPOC) ser uma enfermidade que, além das alterações pulmonares, acarreta inúmeros comprometimentos sistêmicos, torna-se de extrema importância a identificação criteriosa das implicações dessa doença relativas à estabilidade corporal. objetivos: Avaliar o equilíbrio de indivíduos portadores de DPOC por meio da Posturografia Dinâmica Foam Laser. Materiais e métodos: Foram selecionados para a formação do grupo de estudo 29 pacientes (19 homens e 10 mulheres), com média de idade de 64,72 \pm 7,67 anos, ex-tabagistas portadores da DPOC com graus de estadiamento da doença GOLD II e III. O grupo controle foi composto por 24 indivíduos (12 homens e 12 mulheres), com média de idade de 63,58 \pm 8,17 anos, não portadores da doença. Os indivíduos foram submetidos à avaliação do equilíbrio por meio da Posturografia Dinâmica Foam Laser. Resultados: Na realização da Posturografia Dinâmica, quando comparados o grupo de portadores de DPOC e o grupo controle, não foram observadas diferenças significativas $(p<0,05)$ ao serem avaliados os sistemas visual, vestibular e proprioceptivo, por meio dos Testes de Organização Sensorial (I a VI). Além disso, quando comparados, esses grupos não apresentaram diferença significante $(p<0,05)$ nas variáveis de análise sensorial, isto é, funções somatossensorial, visual, vestibular e preferência visual. Conclusão: Este estudo demonstrou que pacientes portadores e não portadores de DPOC apresentaram desempenhos similares nos achados do equilíbrio quando submetidos à Posturografia Dinâmica Foam Laser.

Palavras-chave: Equilíbrio postural. Doença Pulmonar Obstrutiva Crônica. Vestíbulo do labirinto. Propriocepção. Postura.

\section{Introduction}

Body balance is one of the most important functions of the organism. Its importance is partly because balance is the body's ability to maintain stability while stationary or moving (1). Body stability is a complex phenomenon that involves the reception and interaction of sensory stimuli, the planning and execution of movements to control an individual's center of gravity over a small base of support. This process, which comprises a dynamic relationship between perception and action, is performed by the postural control system and coordinated by the central nervous system (CNS) (2). Thus, the postural control is achieved through the integration of information from the vestibular system, the visual receptors and the somatosensory system (3).

Maintaining antigravity postures and giving appropriate responses to balance perturbations depend on the accuracy and integration of all information captured by each system. Thus, any changes in one of these levels may compromise body stability (4).

Imbalance manifestations are quite damaging to individuals, because they may lead to falls, reduced autonomy and worse quality of life. Being aware of the factors that cause balance deficits is therefore essential to reduce its consequences (5).

Chronic Obstructive Pulmonary Disease (COPD) is a preventable and treatable respiratory disease characterized by the presence of (not fully reversible) chronic airflow obstruction. In addition to involving the lungs, it is also accompanied by systemic manifestations, which have a major impact on the quality of life and survival of patients $(6,7)$.

Several studies report that patients with COPD have peripheral muscle weakness, reduced functional mobility and decreased exercise capacity (8, $9,10)$. Furthermore, they also have balance and 
coordination deficiencies, and experience difficulties in their activities of daily living which are associated with disease severity (8).

Thus, taking into account the various changes caused by the disease, this study aimed to assess the balance of patients with COPD by using Foam-Laser Dynamic Posturography.

\section{Materials and methods}

This quantitative, cross-sectional study compared the balance findings between patients with COPD and healthy individuals of the same age.

The study was conducted at the Pulmonary and Otoneurology Outpatient clinics of the University Hospital (HUSM) of the Federal University of Santa Maria (UFSM). Data collection took place between April and August 2011.

The study population was composed of both male and female ex-smokers with COPD, aged over 45 years. All volunteers were selected in the same locations. Inclusion criteria were: male and female gender, older than 45 years, former smokers, COPD patients with moderate Global Initiative for Chronic Obstructive Lung Disease (GOLD II) or severe (GOLD III stage) disease (7), i.e., who had forced expiratory volume in one second (FEV1) $<80 \%$ and $>30 \%$ predicted, and FEV1/forced vital capacity (FVC) ratio below the lower limit of the reference value, i.e., $70 \%$ documented in a pulmonary function test done after bronchodilator use. Another inclusion criteria was having performed the spirometry test at the Pulmonology outpatient clinic of the HUSM within twelve months prior to participating in the study, in accordance with the recommendations for monitoring the natural history of the disease (11).

With regard to the evolution of the disease, we chose to analyze COPD patients in intermediate stages of the disease. This choice was due to the fact that, in the early stage of the disease (grade I) the symptoms are not so obvious, whereas in the most advanced stage of COPD (grade IV) complications arising from the disease could have hindered the assessments.

Being a former smoker was an inclusion criteria because of the fact that the end of exposure to the harmful agent (cigarette) considerably reduces the progression of the disease, resulting in a certain stability, which is characterized as a standardizing factor for the experimental group.
Exclusion criteria were: currently smoking or consuming alcohol, using a joint prosthesis in the lower limbs, having been newly operated, having serious vision and/or hearing deficit, having heart diseases or being hemodynamically unstable, having bone trauma, serious diseases of the nervous system or postural hypotension, or being in acute pain at the time of the study. We also excluded from the study those volunteers who did not complete all the stages of the evaluation.

The study was approved by the Research Ethics Committee of the Federal University of Santa Maria under protocol number 23081.012274.2.010-74 All study participants signed an Informed Consent form, in accordance with Resolution 196/1996 of the National Health Council, Ministry of Health.

29 patients (19 men and 10 women; mean age $64.72 \pm 7.67$ years) were found to be eligible to participate in the study. Of these, 13 patients had GOLD grade II COPD and 16 patients had GOLD grade III COPD.

Ex-smokers were considered to be subjects who had smoked for ten years or more (years-pack) (12) and who had stopped smoking at least one year prior to study start. The cumulative dose of cigarette smoking was expressed as pack-years. One pack-year was regarded as the equivalent of 20 cigarettes smoked per day for one year.

The control group was composed of 24 individuals (12 women and 12 men; mean age $63.58 \pm 8.17$ years) who did not have COPD. These subjects were selected among staff members and caregivers of patients of the HUSM, according to the established age criteria. To fulfill the criteria of this study, another inclusion criteria for these subjects was having normal lung function test results.

To establish the normal range, we performed a spirometry at the Pulmonology Department of the HUSM, using a micro QUARK PC-based spirometer (COSMED Pulmonary Function Equipment). Reference values (13) were adopted to calculate the predicted values. To perform the spirometry testing, we adopted technical procedure, acceptability and reproducibility criteria (14).

To assess the balance of participants, we used Foam-Laser Dynamic Posturography (FLP) (15). The FLP is a simple method for sensory organization tests (SOT). In FSO, the patient is requested to enter into a ( 2 meters high by 1 meter wide) cabin made of a collapsible iron support, wrapped 
in a striped fabric. The 10 -cm-thick, light and dark stripes are meant to create a visual conflict to the subject. A Velcro belt is placed around the patient's waist. Then a laser pen is coupled to the belt in such a manner as to be pointing at a ruler with a centimeters scale fixed horizontally on top of the cabin. Thus, the laser beam shows the anteroposterior displacement of the subject during the six steps of the SOTs, which last 20 seconds each. These steps are described as follows:

- SOT I: patients have their eyes open and look straight ahead; the test is performed on a firm surface, and the cabin is motionless. This test is used to evaluate the visual, proprioceptive and vestibular systems.

- SOT II: patients have their eyes closed; the test is performed on a firm and stable surface. This test assesses the information of the proprioceptive and vestibular systems.

- SOT III: patients have their eyes open; the test is performed on fixed and stable surface and the cabin slowly tilts 20 degrees forward for 10 seconds and then returns to the previous position in the same time interval. This test is used to evaluate the proprioceptive-vestibular system and especially the visual system.

- SOT IV: patients have their eyes open, is motionless and looks straight ahead; the test is performed on 10-cm-thick foam surface with medium density. This test is used to evaluate especially the proprioceptive system.

- SOT V: patients have their eyes closed and are on a $10-\mathrm{cm}$-thick foam surface. This test is used to evaluate the proprioceptive and vestibular systems.

- SOT VI: patients have their eyes open and are on a 10-cm-thick foam surface; the cabin moves slowly forward for 10 seconds, and then backwards for another 10 seconds. This test is used to evaluate the visual, proprioceptive and vestibular systems.

Patients are instructed to remain as stable as possible during the tests. After measuring the amplitude of the anteroposterior displacement in each test, the averages are calculated.

Together with the mean SOT values, we also analyzed the somatosensory, vestibular and proprioceptive functions, as well as the degree of visual preference for maintenance of orthostatic balance. These were calculated as follows:

- Somatosensory Function: SOT II/SOT I;

- Visual Function: SOT IV/SOT I;

- Vestibular Function: SOT V/SOT I;

- Degree of Visual Preference: (SOT III + SOT VI)/ (SOT II + SOT IV)

Data analysis was carried out by using descriptive statistics, including mean and standard deviation. Normality was tested by the Shapiro-Wilk test. The significance of differences between groups was tested by the Mann-Whitney test. The significance level for all tests was 5\%. We used the Statistical Analysis System (SAS), version 9.2, for all analyses.

\section{Results}

We observed that the difference in mean age between the groups was very similar. Thus, this variable did not interfere in the study results (Table 1).

The comparison of the pulmonary function values between the group of patients with COPD and the control group revealed significant differences $(\mathrm{p}<$ $0.05)$, showing the contrast between the groups.

With regard to Foam-Laser Dynamic Posturography, we found no significant differences $(\mathrm{p}<0.05)$ between the experimental and the control group in relation to the variables of the SOT tests (SOT I to VI) or to the variables of the sensory analysis (somatosensory, visual, vestibular and visual preference) (Table 2). The same was also true when comparing individuals who had GOLD II and III (Table 3).

\section{Discussion}

The comparison of the mean pulmonary function values revealed differences between the groups. The values presented by individuals with COPD confirm the airflow reduction caused by the disease. Although spirometry does not globally assess the impact of COPD on the patient's health, it remains the primary test used to diagnose the disease and monitor its progress $(6,7,11)$.

The assessment of balance in clinical practice is essential for an early detection of postural disorders and also for the promotion of appropriate interventions in patients with balance disorders $(16,17)$. 
We chose to use the Foam-Laser Dynamic Posturography in this study because it is a low-cost, fast, relatively easy-to-use method, which provides a good assessment of the systems involved in the control of body balance $(15,16,18)$.

In this study, the greatest difference between the groups was found when comparing the mean values of the results found for in SOT I. Although this difference was not statistically significant, it suggests an increase in body balance in individuals with COPD. This finding is in line with other studies that showed changes in body balance in individuals with $\operatorname{COPD}(19,20)$.

When comparing patients with moderate to very severe COPD with healthy controls, we found that COPD subjects had balance and gait deficits, lower peripheral muscle strength $(10,19)$ and reduced monosynaptic reflexes (21). The decrease in nerve conduction velocity causes a delay in the generation of postural responses, increasing the time of reaction to balance disorders (2).

Table $\mathbf{l}$ - Characteristics of study participants and comparison of lung function mean values

\begin{tabular}{|c|c|c|c|}
\hline & COPD patients & Control Group & \\
\hline Characteristics & $\mathrm{n}=\mathbf{2 9}$ & $n=24$ & \\
\hline Age, years & $64.72 \pm 7.67$ & $63.58 \pm 8.17$ & \\
\hline Gender, M/F & $19 / 10$ & $12 / 12$ & \\
\hline GOLD, II/III & $13 / 16$ & - & \\
\hline Pulmonary Function & & & $p$-value \\
\hline FEV1 (L) & $1.24 \pm 0.43$ & $2.52 \pm 0.44$ & $<0.0001^{*}$ \\
\hline FEV1 \% predicted & $49.15 \pm 10.90$ & $98.70 \pm 10.48$ & $<0.0001^{*}$ \\
\hline FVC (L) & $2.39 \pm 0.66$ & $3.10 \pm 0.63$ & $0.0003^{*}$ \\
\hline FVC \% predicted & $75.87 \pm 13.41$ & $96.82 \pm 11.92$ & $<0.0001^{*}$ \\
\hline FEV1/ FVC \% & $52.38 \pm 9.83$ & $81.87 \pm 4.38$ & $<0.0001^{*}$ \\
\hline
\end{tabular}

Note: $\mathrm{M}=$ male; $\mathrm{F}$ = female; GOLD = Global Initiative for Chronic Obstructive Lung Disease; FEV1 = forced expiratory volume in one second, expressed in liters (L) and percentage of predicted value (\%); FVC = forced vital capacity, expressed in liters $(\mathrm{L})$ and percentage of predicted value (\%). Values are presented as mean \pm standard deviation (except for gender and GOLD stages). The Mann-Whitney test was used to compare between groups. ${ }^{*} p<0.05$.

Table 2 - Descriptive measures and comparison of the values obtained in the Foam-Laser Dynamic Posturography tests performed by individuals with and without COPD

(To be continued)

\begin{tabular}{llrlrrr}
\hline & \multicolumn{2}{c}{ COPD patients } & & \multicolumn{2}{c}{ Control Group } & \\
\cline { 2 - 3 } & Mean & $\begin{array}{r}\text { Standard } \\
\text { deviation }\end{array}$ & & Mean & $\begin{array}{r}\text { Standard } \\
\text { deviation }\end{array}$ & p-value \\
\hline SOT I & 87.3631 & 5.8036 & & 90.14249 & 4.48634 & 0.0782 \\
SOT II & 76.3412 & 15.2343 & & 78.57188 & 7.77636 & 0.4636 \\
SOT III & 72.3810 & 19.5771 & & 72.56292 & 12.89574 & 0.5493 \\
SOT IV & 83.7254 & 6.6779 & & 86.34993 & 5.57937 & 0.2275 \\
SOT V & 60.5354 & 25.0042 & & 65.45145 & 14.43846 & 0.8934 \\
SOT VI & 37.9921 & 43.7820 & & 45.49170 & 32.16431 & 0.9929 \\
SOT MEAN & 69.7230 & 13.8218 & & 73.09507 & 9.05247 & 0.4971 \\
SOM & 87.2407 & 16.5539 & & 87.26987 & 8.67341 & 0.2833 \\
VIS & 96.0856 & 8.2864 & & 96.01618 & 7.72992 & 0.8857
\end{tabular}


Table 2 - Descriptive measures and comparison of the values obtained in the Foam-Laser Dynamic Posturography tests performed by individuals with and without COPD

(Conclusion)

\begin{tabular}{lcccccc}
\hline & \multicolumn{2}{c}{ COPD patients } & & \multicolumn{2}{c}{ Control Group } & \\
\cline { 2 - 3 } & Mean & $\begin{array}{c}\text { Standard } \\
\text { deviation }\end{array}$ & & Mean & $\begin{array}{c}\text { Standard } \\
\text { deviation }\end{array}$ & p-value \\
\hline VEST & 68.7297 & 29.9698 & & 72.73798 & 16.24931 & 0.8582 \\
PREF & 177.3193 & 514.1364 & & 82.30575 & 29.38452 & 1.0000 \\
\hline
\end{tabular}

Note: SOT = Sensorial Organization Test; $\mathrm{SOM}=$ Somatosensorial system; VIS $=$ visual system; VEST $=$ vestibular system; PREF $=$ preferential system. The Mann-Whitney test was used to compare between groups. ${ }^{*} p<0.05$.

Table 3 - Descriptive measures and comparison of the values in the Foam-Laser Dynamic Posturography tests performed by individuals with GOLD II and GOLD III COPD

\begin{tabular}{|c|c|c|c|c|c|}
\hline & \multicolumn{2}{|c|}{ COPD GOLD II } & \multicolumn{2}{|c|}{ COPD GOLD III } & \multirow[b]{2}{*}{$p$-value } \\
\hline & Mean & $\begin{array}{l}\text { Standard } \\
\text { deviation }\end{array}$ & Mean & $\begin{array}{l}\text { Standard } \\
\text { deviation }\end{array}$ & \\
\hline SOTI & 88.1 & 5.45 & 86.77 & 6.19 & 0.5683 \\
\hline SOT II & 76.59 & 17.33 & 76.14 & 13.88 & 0.3921 \\
\hline SOT III & 73.99 & 16.57 & 71.07 & 22.17 & 0.9650 \\
\hline SOT IV & 85.17 & 6.5 & 82.55 & 6.79 & 0.3802 \\
\hline SOT V & 59.21 & 14.12 & 61.61 & 31.7 & 0.0911 \\
\hline SOT VI & 45.98 & 35.62 & 31.5 & 49.63 & 0.6295 \\
\hline SOT MEAN & 71.51 & 9.34 & 68.27 & 16.79 & 0.9650 \\
\hline SOM & 86.96 & 19.57 & 87.47 & 14.32 & 0.5684 \\
\hline VIS & 96.98 & 9.11 & 95.36 & 7.78 & 0.6280 \\
\hline VEST & 67.13 & 15.51 & 70.03 & 38.47 & 0.0832 \\
\hline PREF & 90.11 & 38.81 & 248.17 & 693.02 & 0.661 \\
\hline
\end{tabular}

Note: SOT $=$ Sensorial Organization Test; SOM $=$ Somatosensorial system; VIS $=$ visual system; VEST $=$ vestibular system; PREF $=$ preferential system. The Mann-Whitney test was used to compare between groups. ${ }^{*} \mathrm{p}<0.05$.

The literature states (22) that the SOT I is considered to be simple, because the subjects experience no sensory conflict on the systems. In addition, an unchanged visual information is an important component of the postural control system for maintaining body balance (23). However, the results of the SOT I showed the greatest variation between the groups in this study.

In this study, the individuals of both groups had similar performance in the SOT II (absence of visual information) and SOT III (presence of visual conflict). These results were confirmed by the proximity of the mean values, as well as by the absence of differences in the comparison between groups. It is understood that the effective action of the vestibular system enabled the maintenance of body stability during these tests, thereby ignoring the missing or inaccurate visual information given by these conditions. This finding is in agreement with a study (24) that has reported that, in the absence of some kind of information, a system may, in a compensatory way, increase its ability to perceive the changes of the body and/or environment, thus preventing changes in the maintenance of balance.

When analyzing and comparing the mean values of the SOT IV results, we found no difference between the groups with and without COPD. It is known that COPD causes a decrease in muscle strength and endurance 
(25), which is believed to be associated with deficits in postural balance (20). Patients with COPD have little flexibility and show abnormalities in the thoracic spine, rib cage and sternum joints (26). Thus, on an unstable surface, these subjects were expected to have more difficulty maintaining balance, which was not evidenced in the SOT IV performed in this study.

The conditions of the SOT V and VI require a normal vestibular function in order to maintain the initial position (22). The results of this study suggest no changes related to the vestibular and somatosensory systems in these SOT, since no differences were found between the groups. In contrast, other studies (27) have showed that, when assessing physically active elderly women, the SOT VI was the condition that resulted in the greatest instability in standing position.

According to a prior study (9), deficits associated with the vestibular system, especially in tasks with no visual information, are not expected in patients with COPD. The same study has stated that changes in this group of patients occur primarily in relation to the somatosensory system. Thus, the results found in this study with regard to the vestibular system are in accordance with the aforementioned study. The subjects in this study did not show obvious changes in the somatosensory system. However, the literature reports that this system is usually highly affected in these patients $(9,10)$.

When comparing the mean values of the analysis of the variables of sensory systems (somatosensory, visual, vestibular and degree of visual preference) no significant differences were found. In disagreement with this result, some studies $(7,8)$ suggest that the somatosensory system of COPD patients is more affected than that of healthy subjects. In the same way, another study (19) has reported weakness of the skeletal muscles, reduced strength of the upper limbs and marked decrease in strength and endurance of the muscles of the lower limbs, when compared to healthy subjects (10). In addition, these patients show changes in reflex responses (21), whose function is essential for maintaining body balance.

When examining the values according to the degree of disease evolution, no differences were observed between patients who had GOLD II and those who had GOLD III. Thus, we believe that the degree of airflow obstruction is not a good predictor for quantifying muscle impairments in patients with COPD (28), which would explain the absence of differences between GOLD II and GOLD III patients. However, previous findings indicate that the degree of disease evolution influences subjects' stability (8).

\section{Conclusion}

In this study, we concluded that both groups (with and without COPD) showed a similar performance in the Foam-Laser Dynamic Posturography test.

Thus, further studies with a larger sample size are needed to investigate possible interference of COPD in body balance.

\section{References}

1. Ramos LR, Neto JT, coordenadores. Guia de geriatria e gerontologia. Barueri: Manole; 2005.

2. Paixão CMJ, Heckman MF. Distúrbios da postura, marcha e quedas. In: Freitas EV, Py L, Cançado FAX, Doll J, Gorzoni ML. Tratado de geriatria e gerontologia. 2 ed. Rio de Janeiro: Guanabara Koogan; 2006.

3. Palm HG, Strobel J, Achatz G, von Luebken F, Friemert $B$. The role and interaction of visual and auditory afferents in postural stability. Gait Posture. 2009; $30(3): 328-33$.

4. Peterka RJ. Sensorimotor integration in human postural control. J Neurophysiol. 2002;88(3):1097-118.

5. Rebelatto JR, Castro AP, Sako FK, Aurichio TR. Equilíbrio estático e dinâmico em indivíduos senescentes e o índice de massa corporal. Fisioter Mov. 2008; 21(3):69-75.

6. Sociedade Brasileira de Pneumologia e Tisiologia. II Consenso Brasileiro de Doença Pulmonar Obstrutiva Crônica - DPOC. J Pneumol. 2004;30(Suppl 5):S1-42.

7. Global Initiative for Chronic Obstructive Lung Disease (GOLD) - Global Strategy for the diagnosis, management, and prevention of chronic obstructive pulmonary disease (updated 2010) [Internet]. 2010 [cited 2011 Mar 8]. Avaliable from: http://www.goldcopd.org/guidelinesglobal-strategy-for-diagnosis-management.html

8. Butcher SJ, Meshke JM, Sheppard MS. Reductions in functional balance, coordination, and mobility measures among patients with stable chronic obstructive pulmonary disease. J Cardiopulm Rehabil. 2004; 24(4):274-80. 
9. Chang AT, Seale H, Walsh J, Brauer SG. Static balance is affected following an exercise task in chronic obstructive pulmonary disease. J Cardiopulm Rehabil Prev. 2008;28(2):142-5.

10. Silva EG, Dourado VZ. Treinamento de força para pacientes com doença pulmonar obstrutiva crônica. Rev Bras Med Esporte. 2008;14(3):231-8.

11. Pereira CAC. Espirometria. J Pneumol. 2002;28(Supl 3):1-82.

12. Beauchamp MK, Hill K, Goldstein RS, Janaudis-Ferreira T, Brooks D. Impairments in balance discriminate fallers from non-fallers in COPD. Respir Med. 2009;103(12):1885-91.

13. Knudson RJ, Lebowitz MD, Holberg CJ, Burrows B. Changes in the maximal expiratory flow-volume curve with growth and aging. Am Rev Respir Dis. 1983; 127(6):725-34.

14. American Thoracic Society. Lung function testing: selection of reference values and interpretative strategies. Am Rev Respir Dis. 1991;144(5):1202-18.

15. Castagno LA. A new method for sensory organization tests: the foam-laser dynamic posturography. Rev Bras Otorrinolaringol. 1994;60(4):287-96.

16. Carneiro JAO, Santos-Pontelli TEG, Colafêmina JF, Carneiro AAO, Ferriolli A. Analysis of static postural balance using a $3 \mathrm{~d}$ electromagnetic system. Braz J Otorhinolaryngol. 2010;76(6):783-8.

17. Loth EA, Albuquerque CE, Ciena AP, Rossi, AG. Avaliação do controle postural em adultos jovens através da posturografia dinâmica Foam-laser e plataforma de força. Rev Bras Med Esporte. 2011;17(3):171-4.

18. Loth EA, Rossi AG, Cappellesso PC, Ciena AP. Avaliação da influência do sistema vestibular no equilíbrio de adultos jovens através de posturografia dinâmica posturografia dinâmica foam-laser e plataforma de força. Semina Cienc Biol Saude. 2008;29(1):57-64.

19. Eisner MD, Blanc PD, Yelin EH, Sidney S, Katz PP, Ackerson L, et al. COPD as a systemic disease: impact on physical function limitations. Am J Med. 2008; 121(9):789-96.

20. Roig M, Eng JJ, Road JD, Reid WD. Falls in patients with chronic obstructive pulmonary disease: A call for further research. Respir Med. 2009;103(9):1257-69.
21. Rocco CCM, Sampaio LMM, Stirbulov R, Corrêa JCF. Neurophysiological aspects and their relationship to clinical and functional impairment in patients with Chronic Obstructive Pulmonary Disease. Clinics. 2011; 66(1):125-9.

22. Schmidt PMS, Giordani AM, Rossi AG, Cóser PL. Avaliação do equilíbrio em alcoólicos. Braz J Otorhinolaryngol. 2010;76(2):148-55.

23. Cruz 0, Oliveira EM, Melo SIL. Análise biomecânica do equilíbrio do idoso. Acta Ortop Bras. 2010;18(2):96-9.

24. Kleiner AFR, Schlittler DXC, Sánchez-Arias MDR. O papel dos sistemas visual, vestibular, somatosensorial e auditivo para o controle postural. Rev Neurocienc. 2011;19(2):349-57.

25. Vivodtzev I, Flore P, Lévy P, Wuyam B. Voluntary activation during knee extensions in severely deconditioned patients with chronic obstructive pulmonary disease: benefit of endurance training. Muscle Nerve. 2008;37(1):27-35.

26. Potter HM. Técnicas Fisioterápicas: disfunção músculo-esquelética. In: Pryor JA, Webber BA. Fisioterapia para Problemas Respiratórios e Cardíacos. 2. ed. Rio de Janeiro: Guanabara Koogan; 2002.

27. Teixeira CS, Dorneles PP, Lemos LFC, Pranke GI, Rossi AG, Mota CB. Avaliação da influência dos estímulos sensoriais envolvidos na manutenção do equilíbrio corporal em mulheres idosas. Rev Bras Geriatr Gerontol. 2011;14(3):453-60.

28. Silva KR, Marrara KT, Marino DM, Di Lorenzo VAP, Jamami M. Fraqueza muscular esquelética e intolerância ao exercício em pacientes com Doença Pulmonar Obstrutiva Crônica. Rev Bras Fisioter. 2008; 12(3):169-75.

Received: 01/22/2014 Recebido: 22/01/2014

Approved: 07/30/2014 Aprovado: 30/07/2014 